\title{
A PRESENÇA MARCIÁLICA EM LOPE DE VEGA
}

\author{
Mariana Beraldo Santana do Amaral da Rocha ${ }^{1}$
}

RESUMO: O presente artigo tenciona encontrar possíveis ecos do poeta latino Marcial nos escritos de Lope de Vega. Para isso, optou-se pela comparação entre textos, para assim encontrar estes possíveis ecos do epigramista. Os passos para que o artigo fosse escrito começaram com o estudo sobre o momento histórico deste período, entrando nas leituras sobre a obra do poeta Lope de Vega, perpassando na lembrança sobre o gênero epigramático, com pequenos apontamentos sobre a obra de Marcial, para só assim voltar-se os olhos na presença marciálica nos escritos de Lope de Vega.

PALAVRAS-CHAVE: literatura espanhola; antiguidade clássica; epigramas; Lope; Marcial.

RESUMEN: El presente artículo se propone encontrar posibles ecos del poeta latino Marcial en los escritos de Lope de Vega. Para ello, se optó por la comparación entre textos, para así encontrar estos posibles ecos del epigramista. Los pasos para que el artículo se escribiera comenzaron con el estudio sobre el momento histórico de este período, entrando en las lecturas sobre la obra del poeta Lope de Vega, pasando por el recuerdo sobre el género epigramático, con pequeños apuntes sobre la obra de Marcial, para sólo así se volver los ojos a la presencia marciálica en los escritos de Lope de Vega.

PALABRAS-CLAVE: literatura española; antigüedad clásica; epigramas; Lope; Marcial.

\section{INTRODUÇÃO}

O presente trabalho foi realizado com apoio da Coordenação de Aperfeiçoamento de Pessoal de Nível Superior - Brasil (CAPES) - Código de Financiamento 001. O mote central para sua redação se deu a partir do questionamento sobre a presença dos escritos do poeta Marco Valério Marcial na literatura espanhola, em especial, aquela que se fez presente durante o Siglo del Oro. Será apresentado, nas páginas abaixo, um pequeno estudo sobre o momento histórico deste período, informações sobre vida e obra do poeta Lope de Vega, perpassando pelo estudo sobre a figura do poeta Marcial, como também uma lembrança sobre o gênero que se lançou a escrever, o epigrama, para assim empreender a busca por ecos de Marcial nas linhas de Lope.

\section{UM PANORAMA DO SIGLO DEL ORO}

O termo Siglo del Oro foi concebido por Luis Velázquez, no século XVIII, em Orígenes de la poesia castellana ${ }^{2}$, de 1754. Mais tarde, já no século XIX, George Ticknor consagra o

\footnotetext{
${ }^{1}$ Mestra em Letras Clássicas pela Universidade Federal do Rio de Janeiro (UFRJ). Doutoranda em Letras Clássicas pela Universidade Federal do Rio de Janeiro (UFRJ), sob orientação da Professora Doutora Arlete José Mota. Contato: marianasantanadoamaral@yahoo.com.br
} 
termo em sua History of Spanish Literature, em alusão a Teogonía de Hesíodo ${ }^{3}$. Literariamente, um dos marcos para o início deste período foi a publicação da Gramática Castellana, em 1492, de Antonio de Nebrija, consistindo no primeiro livro impresso dedicado ao estudo da língua castelhana e suas regras, servindo como modelo para os estudos que vieram depois deste. O seu término é marcado pela morte, em 1681, de Pedro Calderón de la Barca, um dos principais nomes do teatro espanhol.

Historicamente, seu início é marcado pela Reconquista da Península Ibérica por parte dos Reis Católicos (por volta de 1490) e a descoberta do Novo Mundo. A Espanha passava por importantes transformações de mentalidade, intensas atividades culturais, solidificando, assim, a língua castelhana, tornando o país uma grande potência. Com Carlos I (1516-1556), a Espanha continua a busca por novos territórios ultramar, em uma época de ímpeto criativo nas artes e na ciência, de onde apareciam as influências italianas e o pensamento reformista. A Espanha adquire prestígio internacional e influência em toda Europa, uma vez que tudo que provinha de solo espanhol passaria a ser imitado em diversas áreas: na literatura, nas artes plásticas, na música, na arquitetura, por exemplo. Felipe II (1556-1598), filho de Carlos I, assume o trono, herdando a expansão territorial de seu pai, entretanto, sofre as primeiras derrotas nos campos de batalha e a derrocada do Estado, uma vez que a Espanha estava envolvida com a luta contra o protestantismo e o espírito da Contrarreforma católica, em 1545, em resposta a Reforma Protestante. Anunciando o alvorecer do Barroco, o Siglo del Oro passava a refletir as circunstâncias de crise, agitação social e tensão religiosa na Espanha daquele tempo.

O país se vê dentro de um boom literário, que durou cerca de cem anos, onde os autores se lançavam a buscar ajuda de patronos aristocratas para conseguirem publicar e vender os seus escritos. Apesar da Igreja ainda ser imperiosa nos escritos dos autores, os poetas deste tempo se lançavam a escrever todo tipo de texto, como os cancioneiros, as poesias de cunho religioso, didático, filosófico, ou político, os romances, as novelas picarescas, as novelas de cavalaria, como Dom Quixote de la Mancha, de Cervantes, e o teatro espanhol, tendo como uma das figuras principais Lope de Vega.

O Siglo del Oro abrange dois períodos estéticos, a saber, o Renascimento e o Barroco. O primeiro pode ser caracterizado como um movimento intelectual, artístico e literário, ocorrido

\footnotetext{
2 ... Luis Josef Velázquez establece las «edades de la poesía castellana», a saber: desde sus orígenes hasta el reinado de Juan II; de Juan II a Carlos I; de Carlos I a Felipe IV... - (... Luis José Velázquez estabelece 'as idades da poesia castelhana', a saber: desde as suas origens até o reinado de Juan II, de Juan II a Carlos I, de Carlos I a Felipe II...). In: https://core.ac.uk/download/pdf/72046101.pdf Acesso feito em 15 de out. de 2018.

${ }^{3}$ A obra de Hesíodo conta como o mundo surgiu a partir dos primeiros deuses e toda a vida que os cercavam, escrito em hexâmetros, constituindo 1022 versos narrados pelo próprio poeta, no século VIII a.C.
} 
na Europa, tendo seu início na Itália, durante os séculos XV e XVI, impulsionado pelo desenvolvimento do comércio, pelo crescimento das cidades, pelo Humanismo, pelo início das Grandes Navegações e pela invenção da imprensa, em 1473, disponibilizando para a população não só grande quantidade de novas obras, mas também a enorme riqueza clássica quase esquecida no período anterior. O momento é marcado pelo ressurgimento do interesse pela cultura Greco-romana, os artistas e intelectuais deste tempo rejeitavam os ideais da Idade Média e buscavam inspiração na Antiguidade Clássica. Enquanto na Idade Média, a vida era regida pela religião, ou seja, pela vontade de Deus, e a ciência, a literatura e a arte eram dependentes da Igreja, o mundo renascentista coloca o homem no centro do universo - antropocentrismo como protagonista de suas ações, reagindo a sua própria vontade. A natureza também atraiu a atenção de poetas e intelectuais deste tempo. Já o Barroco pode ser caracterizado como uma continuação natural do próprio período anterior, pois ambos compartilhavam o interesse pela Antiguidade Clássica. O período se estende do século XVI até o começo do século XVIII, e tinha os olhos voltados para a estética com excessos de ornamentos e rebuscamento, nascendo da interpretação livre das formas clássicas, centrado na dualidade do teocentrismo medieval e do antropocentrismo renascentista. A Espanha foi o centro dos poetas barrocos, e como destaque têm-se os autores Quevedo, Gôngora, Cervantes, Lope de Vega, Calderón, Tirso de Molina, por exemplo.

\section{AS LETRAS DE LOPE}

Isto posto, as letras a seguir tem o intuito de desvendar - ou tentar - o poeta Lope de Vega, uma das figuras mais importantes do Siglo del Oro. Lope é um dos maiores dramaturgos deste período espanhol e, por extensão de sua obra, um dos autores mais profícuos da literatura universal, sendo um dos grandes representantes da poesia e do teatro do final da Renascença e do início do Barroco. Ele reformulou o teatro, foi também poeta lírico e romancista. Seus contemporâneos o deram as alcunhas de Fénix de los Ingenios (Fênix dos engenhos) e Monstruo de la naturaleza (Monstro da natureza), ajudando a criar uma imagem de gênio único, que perdura ao longo do tempo. Entre as qualidades de sua obra estão a fecundidade, espontaneidade, naturalidade e versatilidade, que se unem para compor a genialidade do poeta espanhol. Lope tem clara preferência em escrever o gênero cômico, mais abundante que seus trabalhos em outros gêneros. Antes de avaliar a produção artística de Lope, vale a pena rever os principais fatos de sua vida.

Lope Félix de Vega Carpio nasce em Madri em 1562, o terceiro, ou quarto, filho de Félix de Vega e Francisca Fernández. De vida modesta, as letras sempre foram uma grande 
preocupação do poeta, ele estudou em um colégio da Compania de Jesus e depois nas universidades de Alacá e Salamanca. Foi amigo de Francisco Quevedo, inimigo declarado de Góngora e Cervantes. O poeta foi casado por duas vezes. Seu primeiro amor foi a atriz Elena Osorio, aos 17 anos, que estava divorciada à época. Em sua homenagem, Lope compôs La Dorotea, de 1632, e alguns versos grosseiros relacionados à amante e sua família, em sua juventude. Em consequência, o poeta foi preso e banido de Castela por dois anos e de Madri, por oito anos. Em seu exílio, se casa com sua primeira esposa, Isabel de Urbina, que morre ao dar à luz em 1584. Vive em Valência por um curto período, vai para Lisboa, provavelmente, para se alistar a Armada, em 1588. Seu novo amor fora Micaela Lujan, casada, mas que manteve relações com o poeta durante quinze anos, lhe dando cinco filhos, entre eles, Lope Félix. Mesmo se relacionando com Micaela, Lope se casa, em 1598, com Juana de Guardo, única filha de um rico comerciante. Em 1608, rompe com sua amante, em razão de seus problemas religiosos e o aumento da dedicação para com seu filho nascido em 1606, Carlos Félix.

Em 1612, morre Carlos Félix. No ano seguinte, Juana de Guardo. O poeta sofre uma grande crise emocional. Em 1614, se ordena ao sacerdócio, participando da Inquisição Espanhola ${ }^{4}$. Em 1616, conhece Marta de Nevares, casada com um mercador. Lope vivia momentos de prosperidade econômica devido ao sucesso de suas peças de teatro. Seus últimos quinze anos de vida foram passados com Marta, sua última amante, mas depois de seus primeiros anos juntos, ela fica cega e sofre períodos de insanidade antes de morrer em 1632. Um de seus filhos, Lope Félix, em 1634, morre afogado, e sua filha, Antônia Clara, de 17 anos, neste mesmo ano, fora raptada. Lope morre em 1635, aos 72 anos.

O poeta se destaca como importante dramaturgo e o verdadeiro criador do teatro nacional. Sua produção dramática foi imensa, publicou cerca de mil e quinhentas obras, entre elas, quatrocentas e vinte e seis comédias; e quarenta e dois autos, números que justificam as alcunhas dadas a ele por seus contemporâneos. Esta grande quantidade de obras constitui uma enorme variedade temática de seus escritos, Lope fala de tudo: sobre o mundo religioso, a vida dos santos, as lendas e tradições dos devotos, os temas pastoris e cavalherescos, peças com personagens famosas, sobre as lendas locais, sobre assuntos mitológicos, sobre o próprio povo espanhol. E, juntamente com os dramaturgos Tirso Molina e Calderón de la Barca, renovou as fórmulas do teatro espanhol, em uma época que o gênero começa a ser um fenômeno cultural das

\footnotetext{
${ }^{4}$ A Inquisição Espanhola foi fundada pelos Reis Católicos, Fernando e Isabel, em 1478, e perdurou até $1834 . \quad$ A Igreja a controlava, mas se uma pessoa fosse considerada herege, a punição era realizada pelas autoridades seculares. A tortura era uma das formas mais comuns de punição, mas estas variavam, poderiam ser a vergonha pública, com o uso de uma roupa que indicasse isso, usar uma máscara de metal, mordaças ou até mesmo ser queimado em praça pública, por exemplo.
} 
massas. O poeta se inspira na tradição nacional para compor suas obras com forte cunho dramático, choque das paixões tipicamente espanholas, com sentimento de honra, justiça, em um contraste entre a aristocracia e a massa. Para explicar o que era essa nova comédia espanhola, Lope publica, em 1609, Arte nuevo, como se fosse um guia prático, escrito por um homem que respirava o teatro em plena virada do século.

Também escreveu cerca de mil e seicentos sonetos, uma vez que era uma forma popular e de muito prestígio à época, uma parte está inserida em suas peças e alguns divididos nos livros Rimas, Rimas Sacras, e Rimas del Tomo de Burguillos, e o restante espalhados em prefácios, trabalhos em prosa e em outras coleções de poesia. Para além das peças teatrais, Lope escreveu a novela Arcadia; os poemas épicos La Gatomaquia (1598), La Dragontea (1634), a égloga Amarilis (1633), o épico Iervsalem Conqvistada (1609) e o romance dramático La Dorotea (1632), por exemplo.

O segredo do sucesso de Lope se dá pela capacidade do poeta em compor inúmeras peças de gosto popular e outros textos inventivos e mais sofisticados, visando um grupo mais discreto. Dono de uma criatividade dramática esplendorosa, Lope perpetou caracteristicas únicas neste período. Seu trabalho poético se difere de todos os trabalhos produzidos durante o Siglo del Oro, uma vez que traços de sua vida aparecem em suas linhas, escrevendo com sinceridade, impulsionado por sua vida dada as paixões. Ao longo de suas obras, assume várias facetas que foram sendo adaptadas aos seus respectivos contextos e sua ânsia em alcançar a fama poética e estabilidade financeira.

\section{REDESCOBERTA DOS ESCRITOS MARCIÁLICOS.}

Durante a Idade Média, os textos de Marcial foram destinados a aparecer em edições expurgadas, lidos pelas mais diferentes motivações. É no Renascimento, onde se tem a intensa revalorização dos clássicos, que se passa a re-conhecer os clássicos Greco-latinos, entre tantos, Marcial.

Com a afirmação de que era lido em todo mundo por causa de seus epigramas ${ }^{5}$, o poeta inaugura o seu primeiro livro do conjunto dos Epigrammata, que reúne doze dos quinze livros de

\footnotetext{
${ }^{5} \mathrm{O}$ poeta conta que era famoso no epigrama I, 1, descrito abaixo:
}

Hic est quem legis ille, quem requiris, toto notus in orbe Martialis argutis epigrammaton libellis cui, lector studiose, quod dedisti viventi decus atque sentienti, rari post cineres habent poetae. 
epigrama do poeta. O poeta era espanhol, nasce em Bilblilis (Espanha Terraconense), em março, entre 39/40 d.C. Toda sua lida literária foi tomando forma a partir do findar do reinado de Tito (79-81 d.C.), perpassando todo o principado de Domiciano (81-96 d.C.) e seus últimos escritos são publicados nos reinados de Nerva (96-98 d.C.) e Trajano (98-117 d.C.).

É em 64 d.C que Marcial chega a Roma, ano que a Cidade pegou fogo, ficando sob a proteção do Círculo de Sêneca até o final da Conjuração dos Pisões, em 65 d.C. Sem proteção, Marcial precisa de outro meio para se manter na Vrbs, assumindo a posição de cliens, em busca de agradar aos patronos romanos, conseguir alguns convites para jantar, ou ser pago com uma pequena remuneração - sportula - e passa a vender suas poesias, publicando o seu primeiro livro de epigramas em 80 d.C. A vida em Roma não lhe foi favorável, Marcial começa a sentir saudades do solo pátrio, a Vrbs perde seu encanto inicial, o fazendo retornar a Bilbilis, em 98/99 d.C. Marcial morre em sua terra natal, no ano de 104 ap d.C.

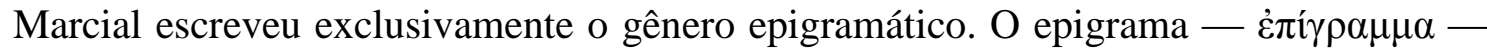
se encontra na fronteira entre o documento e a poesia e era o ato de inscrever sobre uma superfície de pedra, em lápides, monumentos, objetos votivos, tendo como função informar o nome do morto, seu país de origem, ou o nome de algum doador de algo, ou até mesmo em homenagem a algum deus; ou estas inscrições poderiam ser em metal, como troféus ou estátuas. As primeiras inscrições datam do século VIII a.C, e eram informativas e vazias de características literárias, mas funcionavam como constante renovação da memória cultural de um povo. Além disso, nas suas primeiras manifestações, os textos eram escritos em hexâmetros, mais tarde, são substituídos pelo dístico elegíaco. Muitas destas inscrições não possuíam a assinatura de seu autor, uma vez que eram apenas documentos.

Por muito tempo, o epigrama foi considerado um gênero clandestino, já que era considerado como gênero menor, não precisando de uma coletividade para ser lido e por conta do material que era escrito, talhado em materiais resistentes, o excluindo dos momentos performáticos da poesia da época diante de sua plateia. $\mathrm{O}$ momento que o epigrama passa das pedras para as páginas se dá no século IV a.C. Com os helenistas, no século V a.C., passa a ser considerado como gênero poético, tendo seu aparato temático distanciado dos temas fúnebres se aproximando dos temas poéticos. Os helenistas buscavam novas formas de expressão através do

(Eis aqui quem lês e a

quem buscas, o famoso Marcial, conhecido

em todo o orbe por picantes livrinhos de epigramas.

Oh! Leitor aplicado! A honra que deste

àquele que vive e que sente,

raros poetas têm após as cinzas). 
epigrama, trazendo toda a engenhosidade, agudeza e brevidade, características primordiais para a construção do gênero, juntamente ao caráter picante, irônico, jocoso e mordaz. Teve rápida e fácil recepção por parte dos seus leitores, porque tratava do indivíduo e de suas particularidades, inseridos dentro de uma sociedade em constante evolução.

O epigrama avança juntamente com o Império Grego, que expandia o seu domínio, e assim chega ao seu novo lar - Roma. Muitos textos citados por Marcial se perderam no tempo, ou apenas pequenos trechos restam. De antes de Marcial, o único autor que se lançou ao gênero, que se tem a obra em sua totalidade, foi Catulo (87/84 - 57/54 ap a.C.), e apesar de seus textos não serem exclusivamente epigramáticos, imprimiu um novo significado ao gênero. Na Cidade, o gênero começa a narrar sobre os prazeres da vida, torneado pelo humor e o sarcasmo características típicas do gênero. O epigrama, para os poetae $n o v i^{6}$, correspondia a quaisquer tipos de inscrições desde os temas habituais, poderiam narrar os poemas de circunstâncias, falar dos defeitos físicos, em uma tentativa de desmascarar os vícios humanos, ou até poemas licenciosos, podendo ser lugar também para assuntos políticos.

Pode-se dizer que a obra de Marcial foi uma obra multifacetada, e visava os ataques aos vícios do povo romano. Para não utilizar o nome verdadeiro de seus personagens, Marcial recorria a nomes fictícios, dentro de um contexto específico. Nas linhas marciais, se encontram todos os elementos tipicamente epigramáticos: ironia, humor, mordacidade, brevidade, agudeza, etc. O outro lado da moeda também se via em suas linhas, Marcial, quando se lançava a bajular/elogiar alguém, dava o nome verdadeiro do bajulado/homenageado, buscando quaisquer tipos de recompensas. Seus escritos agradavam os romanos, tudo era muito vivo em suas linhas. O leitor se depara com uma gama temática, desde um simples passeio pelas ruas romanas, um fato que acabou de acontecer, as cenas dos banquetes, os banhos públicos, os causos da Cidade, os costumes daquele povo, suas crenças, sendo apresentados quase como caricatura, sem pudor nenhum. O poeta não quer condenar o vício, ele quer apenas demonstrá-lo, sem cair no moralismo. Por fim, é inegável encontrar em suas linhas o bom uso dos gracejos e do humor e um esquema perfeito para a construção dos seus epigramas, deixando em evidência a estrutura bipartida — já conhecida — do gênero: nas primeiras linhas, o poeta conta ao seu leitor toda a situação imaginada, é criada uma expectativa quanto ao desenrolar da história, que é elucidada nos últimos versos, ali o poeta acrescenta um dito espirituoso, um chiste, uma frase mais mordaz, um questionamento.

${ }^{6}$ Eram chamados assim por inaugurar em Roma, do início do século I a.C., uma nova poesia, inspirados pelos neotéricos gregos. 


\section{MARCIAL EM VEGA.}

Como conhecedor dos clássicos, Lope adaptou alguns textos de Marcial, e fez uso deles em suas peças teatrais. Samson e Thacker (2010, pp. 20-21) dizem que Lope se sente influenciado por Marcial, Ausônio, Lucano, Estácio, Juvenal e Claudiano, como também textos de Horácio, Virgílio e Ovídio. Hamilton (1997, p. 250) aponta que Lope foi grandemente influenciado pelos escritos marciálicos, por conta da agudeza e do engenho empreendidos pelo poeta latino.

Assim, partindo das indicações de Sullivan (2005, p. 273), empreendeu-se uma busca primária no site Google Books das obras de autoria de Lope de Vega e, em um trabalho exaustivo, pesquisou-se a seguinte entrada: Lope; epigrama; Marcial, para só então partir em busca de textos do epigramista que comprovassem a emulação realizada por Lope. A seguir, serão apresentados os ecos marciálicos encontrados nas letras de Lope.

O primeiro eco de Marcial a ser mostrado está em Iervsalem Conqvistada ${ }^{7}$, poema épico nomeado pelo próprio poeta como epopeia trágica, dedicada ao rei Felipe, publicada em Lisboa, no ano de 1609. No canto V (p.169), Lope faz referência ao epigrama Spec 27 do epigramista:

Llegaron los monteros presumiendo que el suelto jabalí, que libre estaba, entre la espuma y el gruñido horrendo el anima sangrienta vomitaba: pero el león más espantable viendo, que aquel feroz, que de Hercules la clava venció en Nemea (...)

(Chegaram os caçadores presumindo que o javali solto, que estava livre, entre a espuma e o grunhido horrendo, vomitava a alma sangrenta, mas vendo o leão mais assustador, como aquela fera que a clava de Hércules venceu em Nemeia...).

\section{Spec 27}

Saecula Carpophorum, Caesar, si prisca tulissent, non Porthaoniam barbara terra feram, non Marathon taurum, Nemee frondosa leonem, Arcas Maenalium non timuisset aprum.

(Se as eras priscas ${ }^{8}$, César, criaram o Carpóforo ${ }^{9}$, nem o povo bárbaro, a fera da Etólia, nem Maratona, ao touro; frondosa Neméia ${ }^{10}$, ao seu leão, nem as arcas de Menalio ${ }^{11}$ não temeriam o javali.).

\footnotetext{
${ }^{7}$ Todas as obras de Lope de Vega citadas neste texto se encontram em domínio público.

${ }^{8}$ Segundo o dicionário Aulete, em sua edição online, eras priscas faz referência ao tempo passado, antigamente. Disponível em: http://www.aulete.com.br/prisco Acesso feito em 19 de out. de 2018.

${ }^{9}$ Segundo SARAIVA (2006), Carpophorius seria um nome masculino, favorito de Domiciano.

${ }^{10}$ Mitologicamente, foi em Neméia que Hércules venceu o leão de Hera. Também seria sede dos Jogos Nemeus.

${ }^{11}$ Segundo SARAIVA (2006), Virgilio aponta o termo como monte Menalo. Podendo ser também cantos menalios, isto é, cantos pastoris, idílios como os que cantavam em Arcádia.
} 
Em X, 27, do mesmo livro, diz o poeta: el vengativo Persa en Jerusalên con los triunfales cercos entró del árbol fugitivo - "O vingativo Persa, em Jerusalém, com os triunfais cercos, entrou pela árvore fugitiva". Ecoando ao epigrama de Marcial XI, 43 7-8: Torquebat Phoebum Daphne fugitiva: sed illas/ Oebalius flammas jussit abire puer. — "Dafne ${ }^{12}$, fugitiva, dobrava Febo, mais o jovem Ébalo ${ }^{13}$ mandou partir tais chamas".

Em XVII, 91, Lope emula ao epigrama I, $76 \mathrm{em}$ : del Penneso el agua, que en Beocia nace del fértil Heliconio monte. - "a água de Perneso, que em Beócia nasce o fértil monte Helicon". Abaixo, o epigrama de Marcial:

O mihi curarum pretium non vile mearum,

Flacce, Antenorei spes et alumne laris,

Pierios differ cantusque chorosque sororum; aes dabit ex istis nulla puella tibi.

Quid petis a Phoebo? nummos habet arca Minervae; haec sapit, haec omnes fenerat una deos.

Quid possunt hederae Bacchi dare? Pallados arbor inclinat varias pondere nigra comas.

Praeter aquas Helicon et serta lyrasque dearum nil habet et magnum, sed perinane sophos.

Quid tibi cum Cirrha? quid cum Permesside nuda? Romanum propius divitiusque forum est.

Illic aera sonant: at circum pulpita nostra et steriles cathedras basia sola crepant.

(Ó, dos meus cuidados, o prêmio não vil,

Flaco, esperança e filhos da casa de Antenor, deixe para depois os cantos piérios ${ }^{14}$ e o coro das irmãs ${ }^{15}$, nenhuma das meninas te dará um asse.

O que pedes para Febo ${ }^{16}$ ? A arca de Minerva tem dinheiro, ela é sensata, e a única que dá para todos os deuses;

$\mathrm{O}$ que podem dar as heras de $\mathrm{Baco}^{17}$ ? A árvore de Pala inclina os vários ramos, negras comas.

Além das águas, o Hélicon ${ }^{18}$, das coroas e liras das deusas, nada possui de grande, mas os inúteis bravos.

O que interessa-te Cirra? E as águas de Permeso?

O fórum Romano é mais perto e rico.

Ali soam as moedas de ouro, enquanto em volta de nosso palco, as cadeiras estéreis e os beijos ressoam.).

Em 1611, Lope publica Arcadia, Prosas Y Versos, Con una exposición de los nombres Históricos y Poéticos, seu primeiro poema pastoril, na Exposição, o autor explica que Marcial é

\footnotetext{
${ }^{12}$ Ninfa, filha do rei Peneu, sendo perseguida por Febo (Apolo).

13 Jacinto, filho do rei Ébalo.

${ }^{14}$ Segundo a mitologia, Piério era o pai das nove musas.

${ }^{15}$ Referente às nove musas: Calíope; Clio, Erato, Euterpe, Melpômene, Polímnia, Tália, Terpsícore e Urânia.

${ }^{16}$ Apolo, deus da música, poesia, sol, o mais belo de Roma.

${ }^{17}$ Dionísio, deus do vinho, da ebriedade, dos excessos, especialmente sexuais, e da natureza.

${ }^{18}$ Segundo o site Infopédia, relativo ou pertencente ao monte grego Hélicon, consagrado a Apolo e às Musas.
} 
um poeta latino que nasceu na Espanha e o coloca como exemplo de epigramista. Ainda diz que o epigramista era o autor preferido do Imperador Lúcio Élio, que o chamava de seu Virgílio.

Na comédia, Al pasar del Arroyo (1619), Lope rememora o mito de Leandro e Hero, que era uma sacerdotisa de Afrodite e vivia em uma alta torre, nas margens do Helesponto, Leandro vivia na margem oposta em Abidos. Ele se apaixonou por Hero e todas as noites atravessava o mar para se encontrar com sua amada, guiado pela luz que ela acendia do alto de sua torre. Em uma de suas travessias, Leandro se afogou, vendo o cadáver de seu amado, Hero se junta a ele, se jogando da torre. Na peça citada, Lope, na cena VII, na fala de Don Carlo, faz a leitura do epigrama Spect 25.

\section{Pasaba Leandro un mar, \\ Rompiéndole con sus brazos, \\ Por llegar a los abrazos \\ De quien le pudo obligar. \\ Ya en olas altas, ya en bajas, \\ Una y muchas veces fué, \\ (Passava Leandro por um mar, \\ Rompendo-lhe com seus braços, \\ Por chegar aos abraços \\ de quem poderia obrigá-lo. \\ Já em ondas altas, já nas baixas, uma e muitas vezes foi)}

E conta Marcial:

Cum peteret dulces audax Leandros amores et fessus tumidis iam premeretur aquis, sic miser instantes adfatus dicitur undas:

'Parcite dum propero, mergite cum redeo.'

(Quando Leandro, audaz, buscava amores doces, e exausto as águas túmidas o recobriram, conta-se que o infeliz falou para as ondas erguidas:

- Poupai-me a ida e me afoguem na volta.).

No compilado Justa poética y alabanzas justas, datado de 1620, Lope de Vega relembra Marcial logo na introdução de seu texto (p. 7-8), citando o epigrama VIII, 18, transcrito abaixo:

Si tua, Cerrini, promas epigrammata vulgo, vel mecum possis vel prior ipse legi:

sed tibi tantus inest veteris respectus amici, carior ut mea sit quam tua fama tibi.

Sic Maro nec Calabri temptavit carmina Flacci,

Pindaricos nosset cum superare modos,

et Vario cessit Romani laude cothurni, cum posset tragico fortius ore loqui.

Aurum et opes et rura frequens donabit amicus:

qui velit ingenio cedere rarus erit. 
(Se apresentares ao público teus epigramas. Cerrínio, ou te terão comigo, ou antes, mas tens tanto respeito em ti ao velho amigo, que sejas caríssima a minha fama mais que a tua. Se Marão ${ }^{19}$ não cantas os poemas como Flaco ${ }^{20}$, soube superar com as medidas de Pindáricos e cedeu Vário do coturno romano, como pode falar com a voz trágica. Os frequentes amigos doarão ouro, riquezas e campos, que era raro desejar ceder pelo engenho.).

Em Las fortunas de Diana (1621), peça que tem como mote principal uma jovem, que foge com seu amante, e acaba por descobrir que está grávida, o poeta diz: ... casi en imitación de Marcial, um poeta latino por quien a vuestra merced le esta mejor no saber su lengua. _ “... quase em imitação de Marcial, um poeta latino, por quem a vossa mercê está melhor não saber a sua língua". Já em La Filomena con otras diversas rimas, prosas y versos (1621, p. 158), Lope, entre tantos momentos, menciona Marcial e seu epigrama I, 19: Marcial de Lelia, que no vía, que compraba los dientes, y cabellos, mas que comprar los ojos no podia. - "Marcial disse que Lélia não via que comprava os dentes e cabelos, mas que não podia comprar os olhos”. Segue o epigrama de Marcial:

Si memini, fuerant tibi quattuor, Aelia, dentes: expulit una duos tussis et una duos.

Iam secura potes totis tussire diebus: nil istic quod agat tertia tussis habet

(Se me recordo, tinhas quatro dentes, Élia:

tossiste de uma vez e expeliu dois, e outra vez, mais dois.

Fique tranquila, agora podes tossir por todo dia, não fará nada uma terceira tosse.).

No livro Laurel De Apolo, Con Otras Rimas (1630), em Silva Nona (p.81), Marcial é lembrado pelo poeta espanhol, entre outros poetas de seu tempo, como, Propércio, Juvenal, e poetas que vieram após ele, como Claudiano, Ausônio. No livro Colección de las obras sueltas, assi en prosa, como en verso, Tomo III, na edição de 1776, Lope insere diversos textos de outros autores, fato indicado no prólogo do volume. Assim, Lope insere a versão realizada pelo poeta López de Zarate (1580-1658) para o epigrama X, 47 de Marcial. Abaixo segue a versão usada pelo poeta, como também seu original em latim e sua tradução:

Estas las cosas son que hacen la vida

Agradable, Marcial, más fortunada,

\footnotetext{
${ }^{19}$ Referente a Virgílio.

${ }^{20}$ Referente a Horácio.
} 
Hacienda por herencia, no ganada

Con afán, heredad agradecida.

Hogar continuo, nunca conocida

Querella o pleyto, toga poco usada,

Fuerzas, salud, el alma sossegada,

Sencillez cuerda, amigos a medida.

Mesa sin artificio, leve pasto,

Noche sin embriaguez, ni cuidadosa,

Lecho no solitario, pero casto.

Sueño que abrevie la tiniebla fea;

Lo que eres quieras ser, y no otra cosa,

Ni morir teme, ni vivir desea ${ }^{21}$.

\section{Diz Marcial em seu epigrama:}

Vitam quae faciant beatiorem,

Iucundissime Martialis, haec sunt:

Res non parta labore, sed relicta;

Non ingratus ager, focus perennis;

Lis numquam, toga rara, mens quieta;

Vires ingenuae, salubre corpus;

Prudens simplicitas, pares amici;

Convictus facilis, sine arte mensa;

Nox non ebria, sed soluta curis;

Non tristis torus, et tamen pudicus;

Somnus, qui faciat breves tenebras:

Quod sis, esse velis nihilque malis;

Summum nec metuas diem nec optes.

(Amigo, Júlio, antes do qual ninguém conta-me, se as leis têm crédito e fidelidade nos antigos, já quase o sexagésimo cônsul te segue de perto e com dificuldade a tua vida conta poucos dias. Parece mal que retardes o que pode negar e somente tomes ser teu o que passou.

Esperam cuidados e trabalhos encadeados. as alegrias não permanecem, mas, passageiras, voam.

Segura com as duas mãos e com os braços.

Mesmo assim, escorrem, passando pelo peito.

Não é sábio, creia em mim, dizer: 'Viverei!'

Demasiadamente tarde vem a vida de amanhã: vive o hoje!).

Em Comedias Escogidas de Frey Lope Félix de Vega Carpio, Tomo IV, com a edição de Juan Eugenio Hartzenbusch, de 1860, onde se reúnem algumas comédias do poeta, ali, se

\footnotetext{
${ }^{21}$ Tal afirmação sobre a autoria da versão em espanhol foi apontada por MARISCAL, Gabriel Laguna, In: "Cosas que hacen una vida feliz": los antiguos lo sabían mejor (Disponível em: http://www.uco.es/ callamag/Septiembre2003.htm Acesso feito em 14 de nov. de 2018.). Entretanto, Rosário Moreno Soldevilla (In: Epigramas: Libros 1-7, MADRID: Editorial CSIC, 2004. 676p.), na introdução de seu comentário (p. XLIX), aponta que tal versão é de autoria de Lope de Vega: "El outro gran poeta de la época que adaptó algunas de las piezas de Marcial, fue Lope de Vega (1562-1635), "el Fénix de los ingenios españoles". Destaca su soneto versión del epigrama 10, 47, sobre la vida feliz."
} 
encontram algumas referências a Marcial. No prólogo, dedicado a Baltasar Elisio de Medinilla, poeta e amigo de Lope, por exemplo, o escritor diz:

Ganó tanta fama Persio, no habiendo escrito más que aquel pequeño libro de sus sátiras, por opinión de Marcial y Quintiliano, que a muchos les ha parecido que la hallarían mejor por aquel camino que por el de otras empresas, diciendo bien, difíciles; mas no es pequeño engaño creer que igualan la antigüedad, que apenas imitan, con libertades bárbaras, y siendo más lo que hablan que lo que escriben $^{22}$.

(Ganhou tanta fama, Pérsio, tendo escrito apenas aquele pequeno livro de suas sátiras, na opinião de Marcial e Quintiliano, que para muitos achava que achariam melhor por essa estrada do que por outras empresas, dizendo bem difícil; mas não é pequeno engano para acreditar que eles igualam a antiguidade, que dificilmente imitam, com liberdades bárbaras, e sendo mais o que ela tem do que o que eles escrevem.).

\section{CONSIDERAÇÕES FINAIS}

Fazendo valer as palavras de Marcial, que ele era conhecido em todo mundo, este artigo atingiu o seu objetivo de demonstrar, através dos textos dos dois poetas confrontados, que, sim, o poeta latino fora lido durante o Renascimento espanhol, em uma tentativa de homenagear a engenhosa mente do epigramista, importante fonte sobre Roma nos fins do primeiro século depois de Cristo. Para isso, foi preciso voltar os olhos para os momentos literários à época Renascimento e Barroco - para entender o período do Siglo de Oro espanhol, fase vivida por Lope de Vega. Assim como foi preciso entender o momento histórico e literário, atentou-se ainda a conhecer os pormenores da vida e obra do poeta espanhol, como também de sua fonte clássica, Marcial, voltando à atenção para a vida do epigramista e as particularidades do gênero que escreveu.

Entendendo as circunstâncias histórico-literárias, este artigo pôde se concentrar no foco principal, encontrar ecos marciálicos dentro da obra de Lope de Vega. O poeta se fez valer do caráter prático do epigrama para compor muitos de seus sonetos, fora leitor do Liber Spetaculorum de Marcial para compor seu poema épico Iervsalem Conqvistada, muitos dos textinhos marciálicos serviram como mote para as falas de suas personagens, por exemplo. Assim, Lope também realizou traduções de epigramas ou trechos destes e se valeu do espírito zombeteiro e sarcástico do poeta bilbitiano para deixar um marca na literatura espanhola ao longo do tempo.

\footnotetext{
${ }^{22}$ In http://www.cervantesvirtual.com/obra/santiago-el-verde--0/ Acesso em 10 de out. 2018.
} 


\section{REFERÊNCIAS}

ALBORG, Juan Luís. Historia de la literatura española. Barcelona: Editorial Gredos, 1997. 1082p.

HAMILTON, Albert Charles. The Spencer Encyclopedia. $2^{\mathrm{a}}$ edição. Canada: University Toronto Press, 1997. 858p.

BROWN, G.J. Lope de Vega's Epigrammatic Poetic for the Sonnet. MLN (Modern Language Notes), Vol. 93, $\mathrm{N}^{\mathrm{o}}$. 2, pp. 218-232, Mar.1978. Disponível em: https://www.jstor.org/stable/2906773. Acesso feito em 15 de out. de 2018.

MARTIAL. Epigrams: Volume I: Spectacles, Books 1-5. Edited and translated by D. R. Shackleton Bailey. Loeb Classical Library 94. Cambridge, MA: Harvard University Press, 1993. [?]p.

MARTIAL. Epigrams: Volume II: Books 6-10. Edited and translated by D. R. Shackleton Bailey. Loeb Classical Library 95. Cambridge, MA: Harvard University Press, 1993. [?]p.

MARTIAL. Epigrams: Volume III: Books 11-14. Edited and translated by D. R. Shackleton Bailey. Loeb Classical Library 480. Cambridge, MA: Harvard University Press, 1993. [?]p.

MENÉNDEZ PELÁEZ, Jesús; ARELLANO, Ignacio; GONZÁLEZ, José M.; CASO MACHICADO, María Teresa; MARTÍNEZ CACHERO, José María. Historia de la literatura española, vol II, Renacimiento y Barroco. $2^{\mathrm{a}}$ edição. León: Everest, 2005. 928p.

SAMSON, Alexander; THACKER, Jonathan. (Ed.). A Companion to Lope de Vega (Monografías A). $1^{\mathrm{a}}$ edição. UK: Tamesis Books, 2008. 384p.

SARAIVA, Francisco dos Santos. Novíssimo Dicionário Latino-Português. Rio de Janeiro: Garnier, 2006.

SOLDEVILA, Rosário Moreno. Martial, Book IV: A Commentary. $1^{\text {a }}$ edição. Boston: BRILL, 2006. 636p.

SULlIVAN, John Patrick. Martial: The Unexpected Classical. $1^{\text {a }}$ edição. USA: Cambridge University Press, 2005. 388p.

THACKER, Jonathan. A Companion to Golden Age Theatre (Monografías A). $1^{\mathrm{a}}$ edição. UK: Tamesis Books, 2007. 240 p. 